\title{
HEIGHT INCREMENT OF NATURALLY REGENERATED YOUNG FOREST STANDS OF SCOTS PINE PINUS SYLVESTRIS L. IN MYRTILLOSA FOREST SITE TYPE
}

\author{
Olga MIEZ̄̄TE, Department of Silviculture, Faculty of Agriculture, Latvia University of Agriculture, Akadēmijas 11, Jelgava, \\ LV-3001, Latvia, olga.miezite@1lu.lv \\ Ineta EGLĪTE, Faculty of Agriculture, Latvia University of Agriculture, Akadēmijas 11, Jelgava, LV-3001, Latvia, \\ i.eglite@ inbox.lv \\ Solveiga LUGUZA, Department of Silviculture, Faculty of Agriculture, Latvia University of Agriculture, Akadēmijas 11, Jelgava, \\ LV-3001, Latvia, solveiga.luguza@1lu.lv (corresponding author) \\ Imants LIEPA, Department of Silviculture, Faculty of Agriculture, Latvia University of Agriculture, Akadēmijas 11, Jelgava, \\ LV-3001, Latvia, imants.liepa@1lu.lv
}

One of the most important stand productivity and competition indicators is height annual increment, which is affected by various factors such as soil preparation, initial density as well as various management risk factors. Empirical material for the research was collected in the northern part of Latvia. In four pure Scots pine stands in Myrtillosa forest site type 29 circular plots tree diameter, height and the last five years annual height increment was measured and visual state of health was described. The aim of this research is to analyse Scots pine height annual increment in naturally regenerated young forest stands in Myrtillosa site type forest stands and to give an evaluation of the impact of the initial stand density and the health status on height growth. The mean height increment in studied stands is $0.26 \pm 0.009 \mathrm{~m}$ and the average periodical increment is $0.37 \pm 0.042 \mathrm{~m}$. The annual height increment has been in the height range from 0.23 to $0.53 \mathrm{~m}$. Initial stand density affects the annual height increment significantly. In the stand with an initial density of $5770 \pm 961$ trees the height increment during the last five years has risen by $36 \%$, but in stand with initial density of $12,650 \pm 1,581$ trees $(\mathrm{P}=51.8 \%$ and $\mathrm{R}=6.0 \%)$ the height increment during the five-years period has increased by only $12 \%$. The tree health status does not affect the tree height increment significantly.

Keywords: health status, risk factors of management, stand density.

\section{INTRODUCTION}

Scots pine Pinus sylvestris L. is the most important tree species in Latvian forestry and according to the State Forest Service data - Scots pine occupies $33 \%$ or 995,992.15 ha of the total land area (Gadskārta, 2015). It belongs to helophytes that is characterised by a low tree crown density and needles peripheral layout on branches (Pogrebnak, 1963). Scots pine is one of the tree species which forms up permanent primary forest stands in Latvia. It shows good growth in sandy soils, where it is less infected by fungal diseases compared to mulched and fertilized soil (Brischke et al, 2014). Mesotrophic soil in Myrtillosa forest site type is perfectly suitable for excellent growth of Scots pine (Laiviňš et al., 2008). The Myrtillosa forest type occupies $4.7 \%$ of the total forest area in Latvia (Zālitis, 2006). Where there is a well-aerated mineral soil (podzolic on sandy loam and sand), sometimes occurring in the alluvial horizon with a cemented layer respectively - the litter humus horizon is thin (not more than $5 \mathrm{~cm}$ ), decomposition occurs fast (Bušs, 1981; Kārkliņš et al., 2009). I. Liepa et al. (2014) mention Scots pine Pinus sylvestris L. as the dominant species in Myrtillosa stands composition forming a second site index sustainable and economically valuable stands. One of the most important indicators showing productivity and vitality of the trees in young forest stands is height growth (Jansons et al, 2011). Height increment is influenced by different factors such as soil preparation, initial stand density, as well as biotic factors such as large pine weevil Hylobius abietis L., leaf pine summit Rhyacionia buoliana Den. et Schiff., summer shoot moth Rhyacionia duplana Hbn, pine resin-gall moth Petrova resinella L., European pine sawfly Neodiprion sertifer Geoff., ungulates, pine needle cast Lophodermium spp., Heterobasidion annosum (Fr.) Bref., as well as abiotic factors such as frost. S. Egbäck's et al. (2012) studies in 21 year old stands with three different levels of initial density $(1,100,2,500,10,000$ trees per hectare) indicate that the biggest height was reached in the stand where the initial density was 2,500 trees per hectare, but about a $14 \%$ lower height was reached in stands with the initial density of 1,100 plants per hectare and even lower $(7 \%)$ - in stand with 10,000 trees per hectare. Basing on the above

Copyright (C) 2015 The Authors. Published by Aleksandras Stulginskis University. This is an open-access article distributed under the terms of the Creative Commons Attribution License (CC-BY 4.0), which permits unrestricted use, distribution, and reproduction in any medium, provided the original author and source are credited. 
mentioned, the aim of the study was - to analyse Scots pine Pinus sylvestris L. height increment in young forest stands in Myrtillosa forest site type and to assess the impact of initial stand density and the health status impact on height increment of the trees. The aim was reached by the solving the fallowing tasks: 1) to analyse the Scots pine height increment in young forest stands in Myrtillosa forest site type; 2) to assess the impact of the initial stand density and the health status on the height increment of Scots pine in young forest stands in Myrtillosa forest site type.

\section{MATERIAL AND METHODS}

The sample plots of the researched Scots pine young forest stands were located in the northern part of Latvia - Vidzeme in Trikāta at the elevation of about $53 \mathrm{~m}$ above the sea level. Referring to the data of the Latvian Environment, Geology and Meteorology Centre the following information was obtained - the mean monthly air temperature in the year 2013 was $6.9^{\circ} \mathrm{C}$, the hottest month was July with the mean air temperature of $17.8^{\circ} \mathrm{C}$, while the coldest month was January with the mean air temperature of $6.2^{\circ} \mathrm{C}$. The studied forest stands relief was flat or slightly wavy. Overall 29 circular sample plots (hereinafter SP) with a radius of $3.99 \mathrm{~m}$ and with an area of $50 \mathrm{~m}^{2}$ were established in the four young stands of Scots pine. Each stand coordinates were taken by the GPS device LKS-92, given in the XY coordinates system. Eight of SP were located in block 8 of compartment 354 (XY 593157.57; 382680.74) with an area of 1.9 hectares and species composition 10P7, eight SP - in block 4 of compartment 365 (XY 591106.52 ; 380993.09) with an area of 1.2 hectares and species composition 10P7, six SP - in block 21 of compartment 351 (XY 594711.31; 380993.09') with an area of 0.8 hectares and species composition 10P9 and seven SP - in block 2 of compartment 367 (XY 590892.07; 380643.68) with an area of 1.6 hectares and species composition 10P9. SP were established in random order to collect the empirical data. Within each sample plot the inventory of trees was done, diameter and height and the last five years of height increment was measured. Tree diameter was measured with a calliper (precision $0.1 \mathrm{~cm}$ ). To measure the height of a tree a lath was used. The lath was placed in front of each tree trunk root collar and the tree height was fixed (accuracy $0.1 \mathrm{~m}$ ). To measure the last five years of height increment the lath was positioned to the tree and the height between the tree top and previous year's height growth expiration point was recorded, i.e. from whorl to whorl. Overall 1173 trees were measured in all sample plots. Each tree was visually assessed for damage of abiotic, biotic or anthropogenic risk factors. The observed biotic factors damage impact caused to Scots pine was assessed in grades (Table 1). The damage caused by large pine weevil Hylobius abietis L. was detected by gnawed irregular areas in the bark of tree trunks and branches. The damage caused by pine shoot moth Rhyacionia buoliana Den. et Schiff. was recognized by the gnawed shoots in bottom part, but damage by summer shoot moth Rhyacionia duplana Hbn - by the damaged top shoots (Ozols, 1985). The most commonly observed damage caused by ungulates was stem bark scratches and broken branches. Rodent damage was found as gnawed bark at the root collar (Annila et al., 2006).

Table 1.Abiotic and biotic damage assessment grades (Miezīte et al., 2013b)

\begin{tabular}{|c|l|c|}
\hline No. & Damage assessment & $\begin{array}{c}\text { Damage } \\
\text { grade }\end{array}$ \\
\hline 1. & tree without weakening and growing disturbance signs & 0 \\
\hline 2. & $\begin{array}{l}\text { economically insignificant damage or imperfection (some broken or gnawed branches, insignificant trunk } \\
\text { damage, plaques on the branches and trunks, etc.) }\end{array}$ & 1 \\
\hline 3. & $\begin{array}{l}\text { economically significant damage (one or more tree trunk minor damage, up to half of the circumference of } \\
\text { the trunk, etc.) or imperfection (asymmetric crown; twin top of the tree) }\end{array}$ & 2 \\
\hline 4 & $\begin{array}{l}\text { very severe damage (damage of central shoot, signs of untimely minting; withered, broken or gnawed top } \\
\text { shoot; tree trunk bent and unable to take a vertical position; one or more tree trunk damage, which scars are } \\
\text { bigger than half of the circumference of the trunk; resin areas throughout the length of the tree trunk or } \\
\text { insect holes under the bark or in top layer of the wood }\end{array}$ & 3 \\
\hline 5 & tree withered in the current year (needles and leaves yellow or brown) & 4 \\
\hline 6 & withered tree & 5 \\
\hline
\end{tabular}

Abiotic, biotic and anthropogenic factors tree crown damage was evaluated using the criteria given in Table 2 . Tree crown damage was evaluated in 6 grades. For Laphodermium spp. it was determined if among the brown needles healthy green bundles of needles were found, some needles were greyish in a group of needles, yellow and brown spots and some greyish brown needles. Pine aspen rust Melampsora pinitorqua A., Br. recognized by the blisters shaped damage on shoots and the $\mathrm{S}$ - shaped curved shoots (Annila et al., 2006).

Table 2. Evaluation criteria of tree crown damage (Miezīte et al., 2013b)

\begin{tabular}{|c|l|c|}
\hline No. & \multicolumn{1}{|c|}{ Damage assessment } & Damage grade \\
\hline 1. & tree without weakening and growing disturbance signs & 0 \\
\hline 2. & tree with signs of weakening, 1/4 decrease of amount of needles or leaves & 1 \\
\hline 3. & slightly weakened tree, pruned tree crown, 1/3 needles or leaves weight loss & 2 \\
\hline 4. & withering tree, needles colour yellow-green, 2/3 shoot amount decrease or loss of current year shoot & 3 \\
\hline 5. & tree withered in the current year (needles and leaves yellow or brown) & 4 \\
\hline 6. & withered tree & 5 \\
\hline
\end{tabular}


Average tree height increment in young forest stands was calculated using the formula (1):

$$
Z_{\text {Hvid. }}=\frac{H}{a},
$$

where $\mathrm{Z}_{\text {Hvid. }}$ - average stand height increment (m), $\mathrm{H}$ - average stand height (m), a - stand age, years. Average periodical tree height increment was calculated using formula (2):

$$
Z_{\text {vid.per. }}=\frac{H_{n p}}{n_{p}},
$$

where $\mathrm{Z}_{\text {vid.per. }}$ - average periodical stand height increment $(\mathrm{m}), \mathrm{H}_{\mathrm{np}}$ - average stand height increment in the last five years $(m), n_{p}-$ length of the evaluated time period, years (Liepa, 1996). Only naturally regenerated stands were included in this research.

Tree damage occurrence was calculated using the formula (3):

$$
P=\frac{n \cdot 100}{N}
$$

where $\mathrm{P}$ - tree damage occurrence (\%), $\mathrm{n}-$ number of damaged trees (trees $\mathrm{ha}^{-1}$ ) and $\mathrm{N}-$ total number of measured trees $\left(\right.$ trees ha $\left.^{-1}\right)$.

Intensity of tree damage was calculated using the formula (4):

$$
R=\frac{\sum n_{i} b_{i} \cdot 100}{N \cdot k}
$$

where $\mathrm{R}$ - damage impact intensity $(\%), \mathrm{n}_{\mathrm{i}}$ - number of damaged trees (trees ha ${ }^{-1}$ ), $\mathrm{b}_{\mathrm{i}}$ - damage grade, $\mathrm{N}-$ total number of trees $\left(\right.$ trees $\mathrm{ha}^{-1}$ ) and $\mathrm{k}$ - the highest grade of damage observed. The methodology of tree damage occurrence and tree damage intensity is approbated and is used for risk factors management empirical data processing (Miezīte et al., 2013; Ruba et al., 2013; Ruba et al., 2014).

For determination of the number of trees per hectare, the following formula was used (5):

$$
N=\frac{N_{p} \cdot 10000}{L} \text {, }
$$

where $\mathrm{N}-$ number of trees per hectare according to the account data in sample plots (trees $\left.h^{-1}\right), N_{p}$ - number of trees in sample plot and $\mathrm{L}-$ area of sample plot $\left(\mathrm{m}^{2}\right)$.

Standard error of the average tree height using descriptive statistics was calculated. Accordingly, for the assessment of the stand initial density and incidence and intensity of management risk factors' damaged trees height increment, analysis of a variance was used (Arhipova and Bāliņa, 2003). Microsoft Excel 2010 was used for realisation of mathematical methods.

\section{RESULTS AND DISCUSSION}

\section{Height increment of Scots pine in Myrtillosa}

In first age classes one of the indicators used to evaluate the productivity and competitiveness of the forest stand is height increment. In this study the last five years of height increment trend indicates the high degree of competition among the trees for the nutrients and light. Figure 1 shows that the average height of the periodic increase (ZHvid.per.) is greater than the height of the stand increment (ZHvid.). This shows that over the last five years, the vertical tree growth has increased, indicating that the studied stands are in a state of the beginning of a height culmination period showing an increase in biomass (number of needles) as well as growing parameters.

The biggest increase of annual height was observed in block 21 of the compartment 351 (hereinafter compartment/block) which was a nine years old pure Scots pine stand, which in the year 2010 reached $34 \mathrm{~cm}$ and $53 \mathrm{~cm}$ in the year 2014 (Figure 1). Height increases of individual trees in sample plots in common stand are quite similar, only in one slightly lower. This is explained by the location of the sample plot in the stand. It was located near a clear-cut area that a few years ago was in a maturing age reducing the sun light and the availability of nutrients to the young stand. Edge effect, one of the factors influencing reduced tree height growth, was mentioned by F. Burton (2002). He found that trees growing in the middle of a clear-cut area have 11-37\% higher height increment compared to the ones growing on the edges of the same block, which coincides with this study.

In pure nine years old Scots pine stand - 367/2 annual height increment reached $30 \mathrm{~cm}$ in the year 2010, and in the year $2014-44 \mathrm{~cm}$. There are some differences among the height increase values there. In the terrain of the sample plot where there was a small hill, the values of the increment were significantly lower. Referring to O. Nicodemus et al. (2009) research results, it can be concluded that nutrients were washed downhill, making the soil poorer. But by 
contrast, in sample plots located near the edges of neighbouring groves, Scots pine height was considerably lower, what is also found in J. Ruuska et al. (2008) - the young trees that grow close to the old-growth indicates a much worse tree height increase. The sample plot where the greatest height increase was observed was located close to a road. This affirms that Scots pine belongs to the group of helophyte species previously emphasized by V. Lange et al. (1978), I. Mangalis (2004), A. Mauriņš and A. Zvirgzds (2006).

Smaller changes in average annual height increment was observed in 354/8 seven years old pure Scots pine stand, which in the year 2010 reached $25 \mathrm{~cm}$ but in the year $2014-32 \mathrm{~cm}$. Height increment in all the sample plots was just slightly dispersed, not more than $\pm 4 \mathrm{~cm}$.

Minor changes in the last five years among the Scots pine average annual height increments were detected in $365 / 4$ (10P7) seven year old stand, which in the year 2010 reached $23 \mathrm{~cm}$, but in the year $2014-26 \mathrm{~cm}$. Height increment here was almost the same in all sample plots, except the ones growing in the middle, where they were not affected by the adjacent forest stands trees shading and root competition.

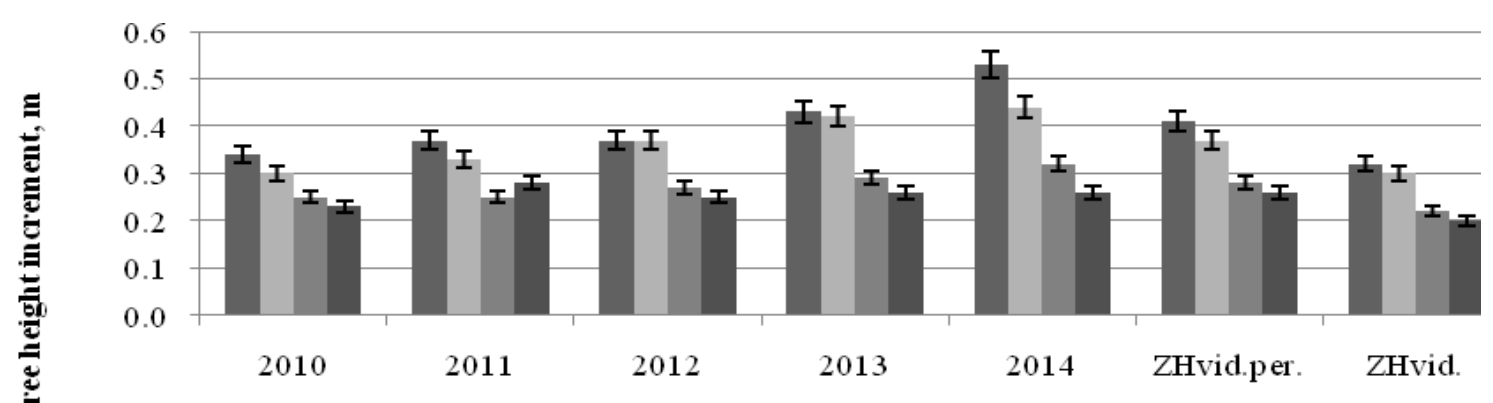

Annual tree height measurem ent year, the average periodical tree height increment, the
average tree height increment

$$
\because 10 \mathrm{P} 9351 / 21 \quad \square 10 \mathrm{P} 9367 / 2 \quad \square 10 \mathrm{P} 7354 / 8 \quad \square 10 \mathrm{P} 7365 / 4
$$

Figure 1. The annual tree height increment, the average periodical tree height increment (ZHvid.per.), the average tree height increment (ZHvid.) of naturally regenerated Scots pine in four forest stands in Myrtillosa site type.

\section{Impact of young forest stand density and health status on height increment in Myrtillosa forest}

Young forest stands of Scots pine have been damaged by needle casts Lophodermium spp., which led to the yellowing and defoliation. The biggest damage was observed in nine year old Scots pine growths where needle cast damage occurrence in 367/2 (10P9) reached 98.1 \% and damage intensity was $15.8 \%$, but in 351/21 (10P9) - respectively $96.0 \%$ and $20.5 \%$ (Figure 2.). Seven year old Scots pine stands have been less affected by needle cast disease - tree damage occurrence in 354/8 (10P7) was $82.6 \%$ and occurrence rate $9.0 \%$, but in 365/4 (10P7) - respectively $51.8 \%$ and $6.0 \%$.

The authors consider that a smaller needle cast infection can be explained by the fact that the forest regenerated naturally from old trees growing also having a higher resistance to needle cast. Evaluating the annual height growth dynamics and occurrence of needle cast damage and intensity, it is concluded that the Scots pine needle casts have not caused a significant impact on the height formation. This can be explained by the recent emergence of the disease in these stands, namely infectious diseases having appeared shortly before the collection of the empirical data.

Damage caused by hoofed animals was also identified. Like in needle casts stands and ungulates tree damage, though not significant most have been recorded directly in both nine year old Scots pine stands. Important tree damage caused by ungulates was detected in 351/21 (10P9) stand, where damage occurrence reached $4.6 \%$ and damage intensity was $2.2 \%$, respectively in 367/2 (10P9) - occurrence $2.3 \%$ and damage intensity $0.6 \%$, respectively in $365 / 4$ (10P7) $-0.4 \%$ and $0.2 \%$. The most commonly observed stands damage caused by hoofed animals was stem bark scratches and broken tree branches. Evaluating ungulates risk factors, the study conducted showed that ungulates killed more formations located near the clearing, but among adults stands damage was less, which coincides with previous studies (Ruba and Miezīte, 2014).

In the nine year old Scots pine stand with the stand density 5,700 \pm 961 (the average \pm standard error) trees per hectare the annual tree increment in the year 2014 comparing to the year 2010 was increased by $36 \%$ but in seven year old stand with the stand density of 6,600 \pm 825 trees per hectare increase was $32 \%$, while in seven year old forest stand with the stand density $12,650 \pm 1,581(\alpha=0.05)$ increase was only $12 \%$. There were significant differences found between the tree annual increment in Scots pine stands with different stand density, $\mathrm{p}=0.0065<\alpha=0.05$.

\section{CONCLUSIONS}

1. From the year 2010 to 2014 annual height increment of seven year and nine year old Scots pine forest stands growing in Myrtillosa forest site type is was a minimum of $23-26 \mathrm{~cm}$ and a maximum of -34 to $53 \mathrm{~cm}$. 
2. In seven year old Scots pine forest stand growing in Myrillosa forest site type stand average height increment was $21 \mathrm{~cm}$, while the average periodical height increment was $27 \pm 0.73 \mathrm{~cm}$, respectively in nine year old one $-31 \mathrm{~cm}$ and $40 \mathrm{~cm} \pm 1.4 \mathrm{~cm}(\alpha=0.05)$.

3. The sanitary state had no significant effect on the height increment of Scots pine growing in Myrtillosa forest site type.

4. There are significant differences between tree height increment in Scots pine young forest stands with different initial stand density in Myrtillosa forest site type, $\mathrm{p}=0.0065<\alpha=0.05$.

\section{REFERENSES}

1. Annila, E., Kytö, M., Lilja, A., Lilja, S., Kurkeela, T. 2006. Kaitēkḷu slimības kokaudzētavās (Pests in tree nurseries). AS Latvijas valsts meži. (In Latvian)

2. Arhipova, I., Bāliņa, S. 2003. Statistika ekonomikā. Risinājumi ar SPSS un Microsoft Excel (Statistics in economics. Solutions with SPSS and Microsoft Excel). Datorzinību centrs, Rīga. (In Latvian)

3. Brischke, C., Meyer, L., Olberding, S. 2014. Durability of wood exposed in ground - Comparative field trials with different soil substrates. International Biodeterioration \& Biodegradation, Vol. 86 (part B), pp. 108-114 http://dx.doi.org/10.1016/j.ibiod.2013.06.022

4. Burton, P.J . 2002 Effects of clearcut edges on trees in the sub-boreal spruce zone of Northwest-Central British Columbia. Silva Fennica, Vol. 36. No. 1, pp. 329-352. http://dx.doi.org/10.14214/sf.566

5. Bušs, K. 1981. Meža ekologija un tipologija (The forest ecology and typology), Rīga, Zinātne. (In Latvian)

6. Egbäck, S., Liziniewicz, M., Högberg, K.-A., Ekö, P.-M., Nilsson, U. 2012. Influence of progeny and initial stand density on growth and quality traits of 21 year old half-sib Scots pine (Pinus sylvestris L.). Forest Ecology and Management, Vol. 286, pp. 1-7. http://dx.doi.org/10.1016/j.foreco.2012.09.003

7. Gadskārta 2015 (Annual Ring 2015). Valsts meža dienesta 2014. gada publiskais pārskats.. Available at https://www.zm.gov.lv/public/files/CMS_Static_Page_Doc/00/00/00/61/87/VMD_PUBLISKAIS_PARSKATS_2014.pdf (accessed on 03/06/2015) (In Latvian)

8. Jansons, Ā., Krišāns, O., Jansons, J. 2011. Parastās priedes (Pinus sylvestris L.) augstuma pieauguma veidošanās sezonālā dinamika (Seasonal height growth dynamics of Scots pine (Pinus sylvestris L.). Mežzinātne, No. 23(56), pp. 15-24. (In Latvian)

9. Kārkliņ̌s, A., Gemste, I., Mežals, H., Nikodemus, O., Skujāns R. 2009. Latvijas augšņu noteicējs (Key-Book of Soils of Latvia), LLU, Jelgava. (In Latvian)

10. Laiviņ̌s, M., Bambe, B., Rūsiṇa, S., Piliksere, D., Kreile, V. 2008. Augu sugu sociologiisko grupu ekoloǵija un ǵeogrāfija Latvijas skujkoku mežos (Ecology and Geography of the Plant Species Sociological Groups in Needle-Leaved Forests of Latvia). LLU Raksti Vol. 20(315), pp. 1-21. (In Latvian)

11. Lange, V., Mauriņš, A., Zvirgzds, A. 1978. Dendrolog̣ija (Dendrology), Zvaigzne, Rīga. (In Latvian)

12. Liepa, I. 1996. Pieauguma mācība (Increment Science), LLU, Jelgava. (In Latvian)

13. Liepa, I., Miezīte, O., Luguza, S., Šulcs, V., Straupe, I., Indriksons, A., Dreimanis, A., Saveljevs, A., Drēska, A., Sarmulis, Z., Dubrovskis, D. 2014. Latvijas meža tipologija (Latvian forest typology), AS Latvijas valsts meži. (In Latvian)

14. Mangalis, I. 2004. Meža atjaunošana un ieaudzēšana (Forest Regeneration and Afforestation), SIA Et cetera, Rīga.

15. Mauriņš, A., Zvirgzds, A. 2009. Dendrolog̣ija (Dendrology) LU Akadēmiskais apgāds. (In Latvian)

16. Miezite, O., Okmanis, M., Indriksons, A., Ruba, J., Polmanis, K., Freimane, L. 2013. Assessment of sanitary conditions in stands of Norway spruce (Picea abies Karst.) damaged by spruce bud scale (Physokermes piceae Schrnk.) iForest, Vol. 6, pp. 73-78.

17. Miezīte, O., Šmits, I., Indriksons, A., Rūba, J., Dreimanis, A., Dağis, S., Luguza, S., Okmanis, M., Āls, R., Polmanis, K., Ozoliṇa, I., Freimane, L., Ozolina, A., Kazāka, R., Kruskops, K., Babris, A., Andžāne, E., Liepiṇa, A., Lupiḳis, A., Poikāns, J. 2013b. Jaunaudžu veselības stāvoḳ̣a analize (Coppices sanitary analysis of the situation). Available at http://maplas.mf.llu.lv/programs/ERAF_Projekta_atskaite_1.3.pdf (accessed on 28/05/2015)

18. Nikodems, O., Kārkliņš, A., Kḷaviņš, M., Melecis, V. 2009. Augsnes ilgtspējīga izmantošana un aizsardzība (Sustainable use and soil protection), LU Akadēmiskais apgāds. (In Latvian)

19. Ozols, G. 1985. Priedes un egles dendrofāgie kukaiņi Latvijas mežos (Pine and spruce dendrofagous insects in Latvian forests), Zinātne, Rīga. (In Latvian)

20. Ruba, J., Miezite, O., Luguza, S., Baltmanis, R. 2013. Abiotic risks of managing young forest stands of Norway spruce (Picea abies (L.) Karst.), Latvia University of Agriculture. Annula $19^{\text {th }}$ International Scientific Conference Proceedings Research for Rural Development, Vol. 2, pp. 27-33

21. Ruba, J., Miezite, O. 2014. Impact of risk factor management on the sanitary condition of Norway spruce (Picea abies [L.] Karst.) pure stands in Latvia. Journal of Forest Science, Vol. 60, No. (5), pp. 181-189. Available at: http://www.agriculturejournals.cz/publicFiles/123241.pdf (accessed on 03/06/2015)

22. Ruuska, J., Siipilehto, J. Valkonen, S. 2008. Effect of edge stands on the development of young Pinus sylvestris stands in southern Finland. Scandinavian Journal of Forest Research, Vol. 23, Iss. 3, pp. 214-226. http://dx.doi.org/10.1080/02827580802098127

23. Zālītis, P. 2006. Mežkopības priekšnosacījumi (The preconditions in the forestry), LVMI Silava. (In Latvian)

24. Погребняк, П.С. 1963. Общее лесоводство (General forestry). Москва, Издательство Сельскохозяйственной литературы Журналов и Плакатов. Pogrebnak, P.S. 1963. Obshee lesovodstvo. Moskva, Izdatelstvo Selskohozjaistvennoi literaturi, Zhurnalov i Plakatov. (In Russian) 